\title{
Contents and Abstracts
}

No. 1(39)/2021

\section{Nature and Society}

Anton I. Kogan. On the socio-natural aspects of formation of traditional livelihood strategy in the Pamir-Hindukush region (pp. 3-27).

The paper attempts at tracing the formation process of one of the two main branches in the traditional economy of the highland peoples of the Pamirs, Hindu Kush and Karakoram, namely, the vertical mobile pastoralism. A notable feature of this subsistence strategy in the region under analysis is the absence of professional shepherds and almost total participation of villagers in vertical migrations. The author shows that this feature could hardly have been brought about by purely economic or ecological reasons, and concludes that its genesis was the result of complex interaction between factors of different nature, among which historical and psychological ones figured prominently.

Keywords: socio-natural history, ethnic ecology, highland peoples, economic history, mountain pastoralism, vertical nomadism, Aryan migrations, the Pamir-Hindukush region.

\section{Theory}

Vladimir I. Pantin. Russia and the West in the 2020s: The prospects of geopolitical revolution (pp. 28-53).

The present article analyses the main shifts in the global system and in the relations between Russia and the West associated with the start of a new geopolitical and geoeconomic revolution (revolution of the global market). It is shown that the growing tension in the relations between Western countries and Russia are long-term and non-accidental. It is caused primarily by the profound social divisions and domestic political conflict in the USA and in the EU countries; and at a global scale - by economic crises and establishment of the new world order, the shift of the center of economic development from the West to the East. Among the mainstream trends that form the outlines of the new world order are strengthening of China and other Asian countries, the delocalization of the global center of political and economic power, the increasing strife in international relations (in particular, in the relations between the collective West and Russia), and the declining economic and political role of the united Europe. With the account of the previously described interaction between the evolutionary cycles of the world political and economic system and the 36-years cycles of the Russian political history there are revealed the major thresholds in the development of the Western countries and Russia during the 2020s, namely: the period from 2021 to 2022, the period from 2024 to 2025 
and from 2029 to 2030. Basing on the correlation of the phases of revolution of the global market as well as on the analysis of current political processes, we make a conclusion that the period from 2021 to 2025 will be especially challenging and full of conflicts; moreover, the domestic political splits in the USA and European countries will provoke regional military and political conflicts between Western states and Russia. We anticipate the reshaping of political systems in Russia and the USA after 2024-2025.

Keywords: evolutionary cycles of the world system, cycles of Russian political history, revolution of the global market, geopolitical shifts, world order, military and political conflicts, USA, EU countries, Russia, China.

\section{Scientific Discussions}

Boris M. Kondorsky. On the statehood issue in the Ukrainian history (pp. 54-81).

By the example of a number of regions, the author demonstrates the influence of historical factors on the nature of modern foreign and domestic policy. The extremely low intensity level of the feudal revolution in Little Russia in the situation of expansion of the Great Duchy of Lithuania hardly contributed to the subsequent political development and only reproduced the recurrences of archaic institutions and practices until modern period. This became a factor that interfered with the further normal state building in the history of Ukraine. Already at the time of the Galicia-Volyn principality, an archetype began to form, which was later reproduced during the period of the Khmelnytsky Uprising, the Ruin, and during the Civil War of 1917-1920, and in modern Ukraine. It is the Ukraine's specific geopolitical position that determined its dependence on neighboring powers, and the lack of unity within the elite, its corporatism, egoism, the struggle for power by all available means including external interference. The presence of elements of statehood in these periods was accompanied by a process of permanent crisis, which often took on difficult forms.

Keywords: statehood in the history of Ukraine, Galicia-Volyn principality, Khmelnytsky region, the Ruin, Civil war in Ukraine 1917-1920, modern Ukraine.

Viktor A. Kovalev. Between Eros and Tanatos: Utopia and Anti-utopia in the works of Ivan Efremov (article two) (pp. 82-110).

The contemporary interpretation of Ivan Efremov's works inevitably differs from the interpretations that prevailed at the time when his novels were written. In his books the connection between utopia and dystopia is actively correlated with the confrontation between Eros and Thanatos, between life and death. The first part of the article examines the socio-historical origins and moral and political contradictions of Efremov's erotic utopia. The second part 
critically analyzes the 'death instinct' that distinguishes totalitarian regimes, and some features of the manifestation of sexuality inherent in the Soviet society. In the third part, the author pays special attention to the connection between utopia and dystopia in Efremov's works with the dangers that threaten civilization, as well as the uniqueness of the worldview and creativity of the writer himself.

Keywords: Eros and Thanatos, utopia and dystopia, socialism, totalitarianism, Ivan Efremov, inferno, utopia studies.

\section{Reviews}

Ivan A. Babosha. The comparative and cognitive analysis of the notion of democracy in the Polish and German public discourse (pp. 111-123).

The monograph of the Polish researcher Monica Grzeszczak is devoted to profiling the notion of democracy in the Polish and German public discourse in the period from 1989 to 2009. Grzeszczak defines two goals of her work: first, to reconstruct the concept as a basic stereotype of democracy in the Polish and German languages fixed in dictionaries and in everyday consciousness; second, to clarify from the collected textual sources which features are attributed to democracy within the Polish and German public discourses. The author represents the famous Lublin school of cognitive ethnolinguistics founded by the famous Poish linguist Jerzy Bartmiński at the Maria Curie-Skłodowska University.

Keywords: public discourse, Modern history, Polish democracy, German democracy, concept, social values.

Contents and Abstracts (pp. 124-126) 